\title{
Why has the crisis been bad for private pensions, but good for the flat tax? The sustainability of 'neoliberal' reforms in the new EU member states
}

\author{
Miroslav Beblavý*
}

No. 356, October 2011

\begin{abstract}
In this paper, we examine two questions related to the sustainability of the major, neoliberal, economic and social reforms in the new EU member states, namely the flat income tax and private pension pillars. First, we look at the relationship between the political consensus/controversy at the time major policy reforms were passed and the future sustainability of these reforms after a change of government. Second, we explore what we call a paradox of reverse sustainability, whereby the flat income tax has been more politically resilient during the global financial and economic crisis than private pensions, even though ex ante expectations and the literature would lead us to expect the opposite.
\end{abstract}

The paper shows that controversy at the time the reforms were passed had no effect on subsequent sustainability, and the levels of partisanship and public support with regard to a specific reform seem less important than the political costs and benefits. We also find that despite their apparent neoliberal bent, the two policies are versatile enough to be shaped towards a variety of policy goals, allowing their introduction and retention in a variety of economic and social circumstances. In other words, even though private pensions and particularly the flat tax have powerful political connotations, they are by no means policy straitjackets.

While both reforms could sustain themselves throughout the 'good' times before the global crisis, their fates diverged during the crisis. Neither public support nor the large constituency of savers could fully protect private pensions from a policy reversal during a period of exceptional fiscal pressure. That is because a reversal was associated with significant, short-term fiscal gains and the states where these reversals took place also took a range of other decisions that were politically extraordinarily difficult. On the other hand, we demonstrate that the introduction or potential reversal of the flat tax was not associated with significant, short-term revenue gains. It is the relatively 'cheap' nature of the flat tax that distinguishes it from private pensions, because it sends a highly cost-effective signal in terms of revenues lost owing to its existence.

* Miroslav Beblavý is a Senior Research Fellow at CEPS, Brussels and an Associate Professor at the Comenius University, Bratislava.

CEPS Working Documents are intended to give an indication of work being conducted within CEPS research programmes and to stimulate reactions from other experts in the field. Unless otherwise indicated, the views expressed are attributable only to the author in a personal capacity and not to any institution with which he is associated.

ISBN 978-94-6138-149-1

Available for free downloading from the CEPS website (http://www.ceps.eu)

(C) Centre for European Policy Studies, 2011 


\section{Contents}

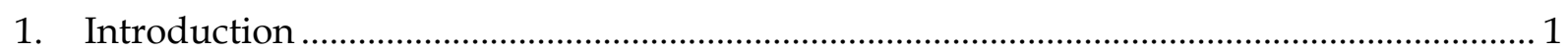

2. Pension and income tax systems and their reforms in Western Europe............................... 2

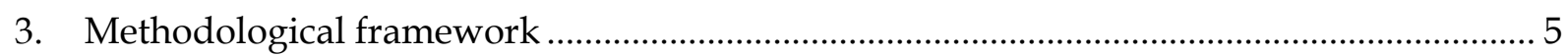

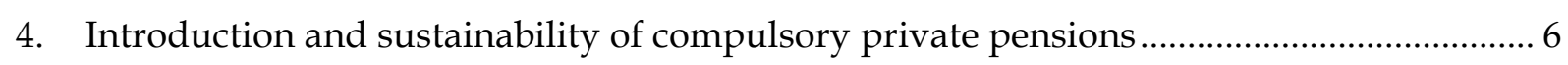

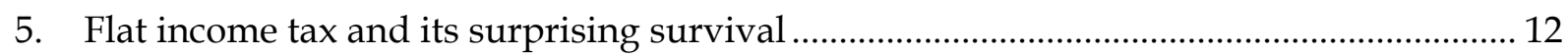

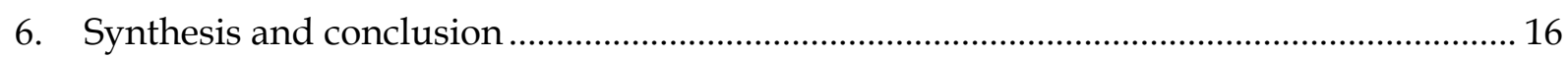

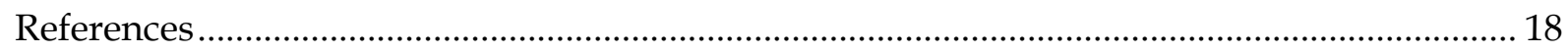

\section{List of Tables}

Table 1. Summary of information on the second pillar reforms in Central and Eastern

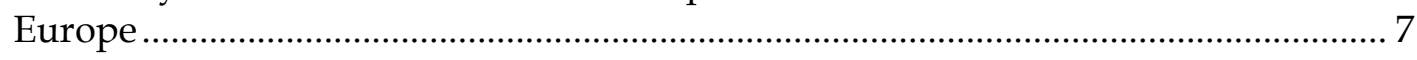

Table 2. Policy changes in the second pillar and other areas as a consequence of the fiscal stress caused by the global financial and economic crisis ..................... 10

Table 3. Basic information on the introduction of the flat income tax.................................... 12

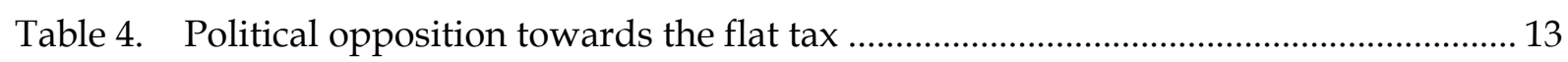

Table 5. Current revenues from taxes on income (\% of GDP) ............................................... 15

Table 6. Revenue from current taxes on income and from social security contributions as a $\%$ of GDP before and after the introduction of a flat tax

Table 7. Influence of various factors on the introduction and sustainability of private pension and flat tax reforms 


\title{
Why has the crisis been bad for private pensions, but good for the flat tax? The sustainability of 'neoliberal' reforms in the new EU member states
}

\section{CEPS Working Document No. 356/October 2011}

\author{
Miroslav Beblavý
}

\section{Introduction}

For governments in the developed world, pension and income tax policies are among the most important and politically sensitive social and economic issues. Both not only present a significant burden (or benefit) for any given individual in society, but also shape the labour market and investment decisions. At the macro level, the fiscal importance of income tax policy is obvious and pension expenditures are now the largest single individual expenditure of all governments in the developed world. Moreover, sending strong signals about the nature and extent of solidarity in a given society, both combine fiscal aspects with competing understandings of moral considerations.

In Europe, one rarely observes paradigmatic reforms of either system in the Western half of the Continent. Despite much talk of welfare state retrenchment and occasional pre-election debates on the introduction of a flat tax, paradigmatic change as understood by Hall (1990), Kuhn (1962) or Masterman (1970) - involving, in our case, a wholesale replacement of existing pension or tax systems with new models - has not happened and does not appear likely. Instead, partial though sometimes far-reaching parametric reforms have been the preferred way forward.

In contrast, the new EU member states have served as a veritable laboratory of social and economic change and policy flexibility. Much of it has been tilted towards ostensibly neoliberal, market-driven policies, such as the flat income tax or large-scale, compulsory, private pension savings.

According to their critics, the flat tax and private pension reforms and the policy mix they represent could threaten the 'European social model', since they put pressure on the policies of old member states through 'unfair' tax and social competition (see Vaughan-Whitehead, 2003 for the most detailed argument along these lines). Even though this is empirically untrue (Draxler \& Van Vliet, 2010), it is also worth saying that while the new member states are in fact highly differentiated internally (Beblavý, 2009), the so-called 'second pension pillar' or flat income tax reforms (or both) have been introduced in nearly all postcommunist EU member states - the only country that has not introduced either is Slovenia. Therefore, the reasons these reforms were introduced and how the reforms have been able to survive politically in an otherwise quite varied landscape are of major interest, given that they have been nearly non-existent in the EU-15.

The purpose of this paper is twofold.

First, we look at the level of political consensus or controversy at the time major policy reforms were passed and examine its relationship with the future sustainability of these reforms. Even a cursory reading of the political discourse reveals that these policies were 
sometimes deeply controversial at the time of their introduction, but passed anyway and have not been repealed after a subsequent change of government despite occasional explicit pledges to do so.

Second, we explore what we call the paradox of reverse sustainability. Neither the private pension reforms nor the flat tax were repealed by the governments that came to power immediately after the reform. Yet the reforms introducing private pensions were, to a large extent, reversed in several countries in the 2008-10 period, during the global financial and economic crisis. While not formally abolished, they were severely cut in Estonia, Latvia, Lithuania and Poland, and effectively aborted in Hungary. In Bulgaria, the attempt to partially nationalise private pension savings, which the parliament passed, was stopped only by the Constitutional Court. This creates a paradox, since it was the flat tax that had originally appeared more susceptible to reversal, given that it was more contested at the time it was passed and it created less path dependency in terms of public expectations and 'rights' than the pension reforms (see section 2 for the review of literature on the topic). Moreover, its abolition presents an electorally attractive option of redistribution (Bohn \& Stuart, 2003).

The rest of the paper is structured into five further sections. In section 2, we review the literature dealing with conditions for the introduction and sustainability of social and economic reforms in general, and pension and tax reforms in particular. Then we propose a methodological approach for our analysis in section 3. While there is a volume of literature examining the introduction of the economic reforms in the post-communist countries, this paper seeks to provide an evaluation of a number of factors and their impact on the longterm sustainability of the reforms and fill the gap in the discussion. The methodology of this paper is based on the testing of two variables - the nature of public and political support, and a cost-benefit analysis of the policy reversal - and their role in the survival of the reform before and throughout the economic crisis of 2008 in the eight studied cases. Two core sections (4 and 5) presenting research findings in each of the two areas follow. Each of the two sections covers the introduction of the reform, the level of controversy and what happened when governments changed, the impact of the crisis, and finally analysis and case studies. In section 6, the paper concludes with a discussion that brings both strands together and summarises our findings. The findings show a relatively stable development of the market-driven tax and pension reforms even after a change of government to parties promising reversals in both areas. The changes in the private pension system occurred only during the economic downturn of 2008, owing to the short-term fiscal benefits of a policy reversal.

\section{Pension and income tax systems and their reforms in Western Europe}

In this section, we briefly look at pension and income tax systems in the developed world, with a focus on their recent reforms (for a new discussion, see for example, OECD, 2011), as we need to place the reforms in new member states in the overall policy context.

The complexity and multidimensional nature of pension system design lead to a variety of potential taxonomies (see Rhodes \& Natali, 2003), but for the purposes of our paper, the distinction between systems with a dominant (or exclusive) public pillar and multi-pillar systems is the most relevant (Bonoli, 2003; Hering, 2006). Dominant public pillars tend to be pay-as-you-go systems (pensions are paid out of current revenue) and can be combined with additional supplementary systems for pension savings, but these are not essential to ensure the adequacy of pensions for recipients. This group includes inter alia Luxembourg, Belgium, Finland, Spain, Portugal, France and Greece (Hering, 2006). 
Multi-pillar systems combine a smaller public pillar aimed at poverty prevention with individual savings in such a way that adequate pensions for most recipients can only be achieved by participation in both schemes (Bonoli, 2003). Multi-pillar systems come in two different models. In one, the savings option is occupational, frequently governed by bisectoral collective agreements and usually without a guarantee of universal coverage. The Netherlands and Denmark fall into this category, although both, and particularly Denmark, have been moving in the direction of universality. The other model is universal in both the pay-as-you-go and the savings pillars, as is the case in Sweden and to some extent the UK (Rhodes \& Natali, 2003).

All developed countries have undertaken some pension reforms over the last two decades, primarily in response to the impact of changing demographics (Barr, 2006; Hering, 2006). As Hering (2006) and Natali (2004) note, however, pension reforms in Western Europe have generally involved parametric changes within the same model. During the 1990s and early 2000s, only Sweden, Italy, Germany and Austria switched from a dominant state pillar to a multi-pillar system, and even this is not as radical as it sounds (Hering, 2006). Only in Sweden did this involve the creation of a universal, private savings pillar of the type that we observe in the new member states. This pillar was quite small, comparatively speaking, with only $2.5 \%$ of contributions diverted to the savings option (Natali, 2004). In the other countries, governments created more space and support for (generally pre-existing) occupational pensions and cut pay-as-you-go benefits (Natali, 2004; Clark, 2006).

The findings from Western Europe are relevant for the issues examined in this paper for two reasons. First, they illustrate path dependency and the resilience of the differentiated forms that welfare states take - ideas associated with Esping-Andersen (1990), Pierson (1994), Pierson (1995) and others. According to this view, choices made at a critical juncture can have difficult-to-reverse effects because massive constituencies coalesce around the new systems for whom any future changes would entail significant costs. Empirically, the organisational paradigms of the welfare regimes applied in individual countries tend to be very sticky (Myles, 1988; Marier, 2008). At the same time, even though welfare states in the industrialised countries of Western Europe and North America underwent significant changes during the 1980s and 1990s, frequently labelled as "welfare state retrenchment", (Pierson, 1995; Castles et al., 2010), this rarely involved paradigmatic change. Castles' analysis (2004) confirms the hypothesis that the welfare state is not losing its position and that the welfare regimes are still keeping their specific profiles ("steady state welfare state") although there are some signs of convergence - a view confirmed by inter alia Ferrera \& Rhodes (2000) and Sapir (2006). These differences between old and new member states make the paradigmatic change in the new member states all the more interesting to study and evaluate.

Hering (2006) also notes that there have been no shifts from a multi-pillar to a dominant state pillar in Western Europe, a finding that has not changed despite the impact of the crisis. In this respect, again Western Europe differs from the new member states, where, as we show, the crisis has led several countries to either move from a multi-pillar system back to a dominant, state pillar system or cut the savings pillar to such an extent that it is debatable where on the borderline between the two systems they find themselves.

Similar to pensions, income tax systems in the developed world present a bewildering variety of features. Still, historically - at least since the mid-20th century - these usually could be labelled 'progressive'. Exceptions, such as Hong Kong, were too few, small and exotic to be of much interest. Progressive income tax has usually been interpreted as involving a multiplicity of rates for personal income tax, although it usually includes a single rate for corporate income tax. 
It is worth noting that income tax policy and its reforms are only an element of wider tax policy and changes therein. Since the 1980s, we can observe two major movements in tax policy for all OECD countries relevant for this paper. One is a general shift from direct to indirect taxes. The other is 'flattening' or lowering the income taxes (or both). As the OECD pointed out (OECD, 2009), this has been a continual process and even in the first decade of the $21^{\text {st }}$ century it has persisted - with the top statutory rate of personal income tax (PIT) decreasing by 3.7 percentage points and the corporate income tax (CIT) rate decreasing by 7 percentage points just between 2000 and 2008. On the other hand, the share of CIT in the total tax revenues has increased in most OECD countries owing to a combination of "basebroadening measures, increased firm profitability as a result of globalisation (at least prior to the crisis) and greater incentives for businesses to incorporate" (OECD, 2010, p. 102).

In this perspective, a flat income tax is a logical (or extreme, depending on one's point of view) conclusion of this process. Nevertheless, even though its introduction has been discussed in the election campaigns of several major economies (e.g. in the US in 1996 and Germany in 2006), it has not been introduced in any Western European country or any nonEuropean OECD country.

On the other hand, post-communist countries ranging from Russia and Georgia to the Czech Republic, Estonia and Slovakia have actually introduced a flat income tax in the last two decades. Conceptually, a flat income tax can be interpreted in a variety of ways, but the most common refers to a personal income tax that has a single tax rate - all income is taxed at the same percentage rate (Keen et al., 2006). As we analyse in more detail below, practical application usually includes two important features (Keen et al., 2006):

- there is a de facto $0 \%$ tax rate for income below a given threshold introduced through an allowance/deduction that is not taxable; and

- $\quad$ in most though not all cases, the tax rate for the personal income tax is made equal to the tax rate for corporate income tax (which is already generally 'flat' in most developed countries).

The shift from direct to indirect taxes and the flattening of the income tax distribution appear to be driven by a combination of an ideological shift and the impact of globalisation (as well as European integration in the case of EU countries) (Inotai, 2000). Yet existing literature on the political economy of tax reform (e.g. OECD, 2010) would give more grounds for scepticism rather than optimism on the adoption and sustainability of a completely flat income tax. Politicians are motivated to focus on attracting "swing voters" and particular groups (Profeta, 2003), leading to "incremental tax reforms that target specific groups and try to create winners without making losers...such as tax expenditures" (OECD, 2010, p. 109). As Bohn \& Stuart (2003) point out, the role of the median voter implies tax redistribution from lower and upper-income taxpayers to the median taxpayer - the opposite of flat income tax reforms. The literature also emphasises a number of factors militating against a radical paradigmatic change in tax policy:

- $\quad$ ex ante uncertainty about distributional impacts and the risk aversion of taxpayers (Fernandez \& Rodrik, 1991);

- the political process may not be conducive to tax reform, owing to coalition governments and the resulting higher number of veto points (Ashworth \& Heyndels, 2001); and

- the collective action problems can be particularly acute in tax policy, with special interest groups having both a vested interest and a strong bargaining position in 
influencing tax policy to block the implementation of tax reform (Olofsgard, 2003), especially in the legislature (Bird, 2004).

The literature thus leads to the following conclusions:

- flattening the income tax structure has been a long-term trend in developed countries, but it is not clear why only the new member states have taken the leap to a completely 'flat' income tax; and

- $\quad$ once instituted, the flat tax is subject to selective pressures that could, over time, erode it.

\section{Methodological framework}

While there is a significant body of literature examining conditions under which major economic reforms are introduced (a good summary is provided by OECD, 2010), much less attention has been paid to factors affecting their sustainability. A good intellectual starting point is the Dewatripont-Roland model (Dewatripont \& Roland, 1992, 1995), according to which the design of reform packages tries to incorporate costs of reversal that are high enough to deter political resistance (see also Cukierman \& Tommasi, 1998). Wyplosz (1993) and Kim \& Pirtilla (2006) conclude that the level of public support influences not only the ex ante political constraints, but also the ex post aspect, i.e. political sustainability. The literature (which is still relatively scarce) is based on analysis of a large number of countries and the overall reform progress. It is also rather general in nature. Therefore, our framework for analysing the sustainability of contested reforms reflects these findings, but fleshes them out based on the specific issues related to the two areas we examine:

- the level of initial public support and the level of partisanship related to the reform as evidenced by

- popular support,

- the positions of political parties, and

- the ideological uniformity/heterogeneity of the parties introducing the reforms; and

- $\quad$ the costs and benefits of policy reversal, decomposed into

- the political costs and benefits (interest groups, path dependency), and

- the fiscal costs and benefits (short-term costs/benefits, level of fiscal pressure on the government).

Based on the literature, we can hypothesise that the level of initial public support and the strength of partisanship related to the reform should be correlated with the reform's sustainability. Reforms that are more contested in public opinion or 'owned' by one part of the political spectrum and opposed by the other should have a smaller chance of survival. This should apply comparatively - i.e. comparing the fate of the same reform among countries, but also comparing different types of reforms.

We measure the level of controversy based on a combination of publicly available information about the position of the public and the political parties towards the reform during the reform and in the run-up to the subsequent elections. When a high level of public support was combined with the support (or at least acquiescence) of major political parties and interest groups, we consider the reform to demonstrate a low level of controversy. When the popular or political reaction was more mixed, but there were no explicit promises of 
reversal by the opposition parties, this was coded as a medium level of controversy. When the opposition as well as some of the major interests (usually trade unions) were opposed and the opposition explicitly promised major changes, then we see the reform as highly controversial. We also examine the ideological hues of the governments that introduced each reform to see whether there was an ideological bias. ${ }^{1}$

In our framework, the costs and benefits of policy reversal are divided into political and fiscal elements. In the political arena, we examine costs and benefits by looking at both the pre-existing positions of key interest groups before the reform was introduced and at any lock-in effects of the reform after its introduction - through, for example, the creation or empowerment of new interests. With regard to fiscal costs and benefits, we look at shortterm fiscal costs/savings resulting from a particular reform and the overall level of immediate fiscal stress of the government, which mediates how politically important the short-term costs or savings are.

\section{Introduction and sustainability of compulsory private pensions}

The second pillar reforms within the Central and Eastern European context are an important element of liberal changes in economic and social policy, as they mean a partial privatisation of the public pension system. The introduction of a compulsory, private pension pillar to complement the existing, public, pay-as-you-go system has been part of the formal World Bank pension strategy since 1994. The countries of Central and Eastern Europe have generally been most responsive to the Bank's argument that such an approach

allows a distinction to be made between poverty reduction and income replacement goals; it builds risk diversification into a country's provisions for retirement income support; it minimizes the burden of fiscal transition while preserving many of the economic gains of the fully-funded approach; and it brings to the reform discussion some clear gains for younger workers and those who are facing labour income losses from globalization (Holzmann, 1999).

The size of the pillar can differ dramatically, however, and the introduction of the pillar can have regressive as well as progressive consequences in terms of income redistribution effects, depending on the balance between the second pillar and the publicly provided, pay-as-yougo system (the first pillar), and particularly depending on the nature of the first pillar pension formula. In Central and Eastern Europe, except for the Czech Republic and Slovenia, all the countries have privatised parts of their pension systems, but their size differs. (The Czech Republic is currently in the process of creating a second pillar, but the legislation has not been passed yet.) Using the yardstick of what percentage of the gross wage is diverted to private accounts, the systems were intended to be large enough to make them multi-pillar, with the private pillars being larger than those found in the multi-pillar systems of Western Europe. Even so, they were not expected to completely replace the public pay-as-you-go systems, as was the case with several Latin American reforms.

Table 1 presents key information on the introduction of the second pillar in eight new EU member states and its political economy. As we can see, the private pension pillars were introduced during the decade between 1998 and 2008, though generally prior to EU accession.

\footnotetext{
${ }^{1}$ In our analysis, we generally omit the role of international institutions even though they played an important part in the introduction of the second pillar (not the flat tax), since their role in the sustainability of either type of reform appears to be negligible.
} 
Table 1. Summary of information on the second pillar reforms in Central and Eastern Europe

\begin{tabular}{|c|c|c|c|c|c|}
\hline Country & $\begin{array}{l}\text { Year the 2nd } \\
\text { pillar was } \\
\text { introduced }\end{array}$ & $\begin{array}{l}\text { Planned size } \\
\text { ( } \% \text { of gross } \\
\text { wage) }\end{array}$ & $\begin{array}{l}\text { Govt } \\
\text { composition }\end{array}$ & $\begin{array}{l}\text { Level of } \\
\text { controversy of } \\
2^{\text {nd }} \text { pillar } \\
\text { introduction }\end{array}$ & $\begin{array}{l}\text { Year when } 2^{\text {nd }} \text { pillar } \\
\text { opponents entered } \\
\text { the government and } \\
\text { the consequences }\end{array}$ \\
\hline Hungary & 1998 & $\begin{array}{l}8 \% \\
\text { (increasing } \\
\text { from 6\%) }\end{array}$ & Centre-left & High & $\begin{array}{l}1998 \text { (Fidesz), freezing } \\
\text { increases in the size of } \\
\text { contributions at } 6 \% \text {, } \\
\text { temporary opt-out } \\
\text { from the } 2^{\text {nd }} \text { pillar } \\
\text { until } 2002\end{array}$ \\
\hline Poland & 1999 & $7.20 \%$ & Centre-right & Low & - \\
\hline Bulgaria & 2001 & $\begin{array}{l}5 \% \\
\text { (increasing } \\
\text { from } 2 \% \text { ) }\end{array}$ & Centre-right & Medium & 2001, no consequences \\
\hline Estonia & 2002 & $6 \%$ & Centre-right & Low & - \\
\hline Latvia & 2001 & $\begin{array}{l}10 \%- \\
\text { reached } 8 \% \\
\text { before the } \\
2009 \text { cut }\end{array}$ & Centre-right & Low & - \\
\hline Lithuania & 2004 & $5.5 \%$ & Centre-right & Low & - \\
\hline Slovakia & 2005 & $9 \%$ & Centre-right & High & $\begin{array}{l}2006 \text { (SMER-SD), } \\
\text { allowing a temporary } \\
\text { opt-out }\end{array}$ \\
\hline Romania & 2008 & $\begin{array}{l}6 \% \text { by } 2016 \\
\text { (increasing } \\
\text { from } 2 \% \text { ) }\end{array}$ & Centre-right & Medium & $\begin{array}{l}\text { No major change of } \\
\text { government yet }\end{array}$ \\
\hline
\end{tabular}

Source: Author's compilation, using data from the World Bank and European Bank of Reconstruction and Development.

Ideologically, there is a clear pattern of the reform being introduced by governments right of the centre, the only exception being the Hungarian 1998 reform. (Even in the Hungarian case, the ostensibly centre-left 1994-98 government introducing the reform was, on the whole, characterised by sustained attempts at liberal reforms in all areas as a solution to the country's long-lasting fiscal problems.)

Based on the methodology presented above, we analysed the level of public and partisan controversy surrounding the pension reform (see Table 1). We find that the introduction of the private pensions was, in most cases, not politically contested. Let us now analyse the consequences of controversy where they existed. In the two countries with a medium level of controversy, either nothing happened (Bulgaria) after the subsequent change of the government or there has not yet been a change of government to the parties criticising the reform (Romania). Two countries with a high level of controversy - Hungary and Slovakia are subject to a more detailed analysis.

In Hungary, we draw information primarily from Simonovits (2009). The second pillar was introduced in 1998, six months prior to the parliamentary elections, by a government dominated by post-communist Socialists, but also containing Liberals. The reform diverted contributions worth $6 \%$ of the gross wage into private accounts (to be increased to $8 \%$ by 2000 ) in exchange for a loss of $25 \%$ of the first pillar pension. Entry into the system was completely voluntary for everyone already in the labour force and mandatory for new entrants. 
The conservative opposition party Fidesz heavily criticised the system and pledged to abolish it after the election. Once elected, it chose not to do so to avoid political controversy in light of the popularity of the new policy (see below), instead taking three different steps:

- freezing the contribution rate at $6 \%$,

- $\quad$ allowing individuals to return to the mono-pillar system until 2002, and

- making participation in the multi-pillar system voluntary even for new entrants.

The second pillar proved to be extremely popular, particularly among younger people. Among workers, $81.2 \%, 83.8 \%$ and $75.9 \%$ in age brackets $20-24,25-29$ and $30-34$ respectively decided to join. Even the significant decrease in the attractiveness (caused by the $6 \%$ instead of $8 \%$ contribution rate without a corresponding change in the $25 \%$ loss of the public pension) coupled with a major political attack on the new system by the government did not cause a significant exodus from the multi-pillar system.

After the 2002 election, the Socialist-Liberal government returned, increasing the rate to the originally planned $8 \%$ and making participation for new entrants mandatory again.

In Slovakia, we base our analysis on Žitňanský (2009). The second pillar was introduced as part of the overall overhaul of the pension system in 2005 by a centre-right coalition, 18 months before parliamentary elections. It entailed exchanging the loss of $50 \%$ of the public pension for diverting $9 \%$ of the gross wage in contributions to the individual accounts. The entry was voluntary for all workers, but mandatory for new entrants.

The main opposition party SMER, which used its animosity towards the overall social and economic policy of the government as its main political platform, was particularly critical of the second pillar. It saw the second pillar as a way of weakening the state and handing over public money to private pension funds. Its election manifesto promised to abolish the second pillar by making it completely voluntary. After the election, SMER became the core of the new government and continued its attacks on the second pillar by

- $\quad$ enacting two temporary 'return windows' in 2008 and 2009, when people could return to the mono-pillar system; and

- $\quad$ making participation in the multi-pillar system voluntary even for new entrants.

It also repeatedly hinted at reducing the contribution rate from $9 \%$ to $6 \%$, but has not done so yet.

The Slovak private pillar, despite less attractive conditions, proved to be comparably popular to the Hungarian case. Again among workers, $87.6 \%, 86.4 \%$ and $89.5 \%$ in age brackets $20-24$, 25-29 and 30-34 respectively decided to join. ${ }^{2}$

Therefore, the level of controversy and partisanship had no measurable effect on the initial sustainability of the second pillar reforms.

Shifting now to political costs and benefits - from a fiscal point of view aborting or cutting the second pillar would bring an immediate fiscal benefit. The stability and growth pact means that the transition costs of the second pillar (due to the fact that while contributions are diverted to private savings, current pensions still have to be paid) are calculated into fiscal deficits. In other words, second pillar reforms make the implicit debt in the pay-as-yougo pillar into an explicit, immediate fiscal deficit and debt. This resulting situation is that

\footnotetext{
2 These percentages are slightly overstated, as the rules also allowed certain groups of non-working individuals to participate.
} 
even though the pension reforms introduced in Hungary and Slovakia will reduce public debt in the long run, they increase the fiscal deficit in the short- to medium-term period. Thus the abolition or reduction of the private pension pillar would mean a relaxation of immediate fiscal constraints.

Therefore, one needs to answer the question of why - even in countries where all of these factors would militate against the sustainability of the private pensions - they have survived a change of government with only minor adjustments. Their survival can be primarily ascribed to the path dependency and resilience of the welfare state outlined in section 2 . The case of the second pillar shows that this path dependency logic can also be applied to liberal, privatising reforms when they create a politically important constituency - in this case, millions of voters who have entered the second pillar. Of course, this sustainability is predicated on the initial and continuing enthusiasm of these voters for the second pillar. Public support was demonstrated even in countries with a high level of controversy, such as Hungary and Slovakia. One should also bear in mind the relative weakness of the interests fighting against the second pillar, particularly trade unions in post-communist countries. The trade union density in Hungary and Slovakia is $17 \%$ and $22 \%$ respectively (Kohl, 2008) and the pattern is followed everywhere else in the region $(11-22 \%$ for the new member states with the notable exception of Slovenia, which has a density of $44 \%)$. Even these numbers do not paint the full picture of trade union weakness. Until 1990, membership had been compulsory. The numbers for the trade union density therefore reflect inertia to some extent, which decreases their mobilisation powers. For example, in Hungary there was a decrease of 46 percentage points (from 63\% to 17\%) between 1995 and 2008, while in Slovakia there was a decrease of 35 percentage points (from $57 \%$ to $22 \%$ ) over the same period - the highest declines among the post-communist new member states (Kohl, 2008).

Additionally, subsequent governments faced only limited fiscal pressure. After 1998, Hungary enjoyed a period of high economic growth and declining unemployment, as did Slovakia after 2006. Among the countries with a medium level of controversy, we can only analyse the case of Bulgaria, where the period after 2001 was also associated with an economic upswing. This is likewise true for countries where private pensions were uncontroversial (Estonia, Latvia, Lithuania and Poland).

In the end, it was the advent of the global financial and economic crisis that changed the political calculus. It was not the case that the costs and benefits related to interest groups and path dependency suddenly changed. There is no evidence of a change in the popularity of the second pillar among the wider population.

The extreme fiscal stress associated with the global crisis created a new reality in several new member states, in which major cuts in the second pillar were suddenly possible. Table 2 shows the extent to which the private pensions were downsized in nearly all the countries that have them. In Hungary, the private pensions were effectively abolished and existing savings nationalised. In Estonia, all payments were suspended for two years and cut by $50 \%$ in the following year. In Lithuania, Latvia and Poland, the pillar was cut by $60 \%$ to $75 \%$. Only in Romania and Slovakia were the changes minor or absent. In the Czech Republic, which is currently passing legislation to create the second pillar, the size of the contribution diverted from social security contributions should be small and should involve matching funds from individuals.

If sustained, these are not just parametric changes. Even though a much smaller, private pillar survives, it can no longer serve as an equal or significant addition to the public system. Instead, it becomes a small supplement, which means that the entire pension system reverts to a state-dominated one. 
Table 2. Policy changes in the second pillar and other areas as a consequence of the fiscal stress caused by the global financial and economic crisis

Country $\begin{aligned} & \text { Changes in the size of } \\ & \text { the } 2^{\text {nd }} \text { pillar during the changes in pensions, taxes and public sector } \\ & \text { crisis }\end{aligned}$

\begin{tabular}{|c|c|c|}
\hline \multirow[t]{3}{*}{ Bulgaria } & \multirow{3}{*}{$\begin{array}{l}\text { The nationalisation of } \\
\text { savings from individual } \\
\text { accounts of older } \\
\text { workers (passed in } \\
\text { parliament) was } \\
\text { declared illegal by the } \\
\text { Constitutional Court }\end{array}$} & $\begin{array}{l}\text { Increase of the retirement age for both men and women } \\
\text { from } 63 \text { and } 60 \text { respectively to } 65 \text { by } 2026 \text { (starting 2017) }\end{array}$ \\
\hline & & $\begin{array}{l}\text { Increase of employer (from } 8.9 \% \text { to } 10 \% \text { ) and employee } \\
\text { (from } 7.1 \% \text { to } 7.8 \% \text { ) contributions; increase in the number } \\
\text { of contribution years required from } 37 \text { to } 40 \text { years by } 2020 \\
\text { (2011) }\end{array}$ \\
\hline & & Public sector wages and jobs cut by $10 \%$ (2010) \\
\hline \multirow[t]{5}{*}{ Estonia } & \multirow{2}{*}{$\begin{array}{l}\text { From } 1 \text { June } 2009 \text { to } 31 \\
\text { December 2010, state } \\
\text { contributions to funded } \\
\text { pensions were } \\
\text { suspended }\end{array}$} & $\begin{array}{l}\text { Increase of the pension age from } 63 \text { for men and } 60 \text { for } \\
\text { women to } 65 \text { (starting 2017, finishing in 2026) (2010) }\end{array}$ \\
\hline & & $\begin{array}{l}\text { Increase of the maximum unemployment insurance } \\
\text { contributions for both employees (from } 2 \% \text { to } 2.8 \% \text { ) and } \\
\text { employers (from } 1 \% \text { to } 1.4 \% \text { ) (2009) }\end{array}$ \\
\hline & \multirow{2}{*}{$\begin{array}{l}\text { In } 2011 \text {, the } \\
\text { contributions were } \\
\text { resumed on a } 1+2 \% \\
\text { basis }\end{array}$} & Public sector wages cut by $8 \%$ \\
\hline & & Increase in the VAT rate from $18 \%$ to $20 \%$ (2009) \\
\hline & $\begin{array}{l}\text { In } 2012 \text {, the initial } 2+4 \% \\
\text { system is expected to be } \\
\text { restored* }\end{array}$ & \\
\hline \multirow[t]{5}{*}{ Latvia } & \multirow{5}{*}{$\begin{array}{l}\text { Reduced from } 8 \% \text { to } 2 \% \\
\text { in May } 2009 \text { with a plan } \\
\text { to gradually return to } \\
6 \% \text { by } 2012 \text { (not } \\
\text { adhered to) }\end{array}$} & $\begin{array}{l}\text { Increase of the retirement age for both men and women } \\
\text { from } 62 \text { to } 65 \text { by } 2021 \text { (starting 2016) }\end{array}$ \\
\hline & & $\begin{array}{l}\text { Reduction of early retirement pensions from } 80 \% \text { of the } \\
\text { normal retirement pension, to } 50 \% \text { of the normal } \\
\text { retirement pension (2008) }\end{array}$ \\
\hline & & Abolition of early retirement as of 2012 \\
\hline & & Public sector wages cut by $15-50 \%$ \\
\hline & & $\begin{array}{l}\text { Increase in the VAT rates: the standard rate rose from } 18 \% \\
\text { to } 21 \% \text {, the reduced rate rose from } 5 \% \text { to } 10 \%(2009) \text {, and } \\
\text { further increased to } 22 \% \text { and } 12 \% \text { respectively (2011) }\end{array}$ \\
\hline \multirow[t]{5}{*}{ Lithuania } & $\begin{array}{l}\text { Reduced from } 5.5 \% \text { to } \\
2 \% \text { (as of 2011) now }\end{array}$ & $\begin{array}{l}\text { Increase of the retirement age for both men (from 62.5) } \\
\text { and women (from 60) to } 65 \text { by } 2026 \text { (2011) }\end{array}$ \\
\hline & \multirow{4}{*}{$\begin{array}{l}\text { Proposes that if an } \\
\text { individual is willing to } \\
\text { put in an additional } 2 \% \text {, } \\
\text { the government will } \\
\text { match that voluntary } \\
\text { amount; the plan is to } \\
\text { go to } 6 \% \text { for } 2012-14 \text { ) }\end{array}$} & $\begin{array}{l}\text { Temporary reduction of pensions above LTL } 650 \text { by ca. } \\
5 \%(2010-11)\end{array}$ \\
\hline & & Public sector pensions cut by $11 \%$ \\
\hline & & Public sector wages cut by $8-10 \%$ (2010) \\
\hline & & $\begin{array}{l}\text { Increase in the VAT rate from } 18 \% \text { to } 19 \% \text { (2008), further } \\
\text { increased to } 21 \%(2009)\end{array}$ \\
\hline
\end{tabular}


Table 2. cont'd

\begin{tabular}{|c|c|c|}
\hline \multirow[t]{6}{*}{ Hungary } & \multirow{6}{*}{$\begin{array}{l}\text { Suspension of payment, } \\
\text { quasi-nationalisation } \\
\text { and automatic } \\
\text { withdrawal from the } 2^{\text {nd }} \\
\text { pillar with a mandatory } \\
\text { opt-back }\end{array}$} & $\begin{array}{l}\text { Increase of the retirement age to } 65 \text { for men by } 2018 \text { and } \\
\text { for women by } 2020 \text { (starting 2012) }\end{array}$ \\
\hline & & $\begin{array}{l}\text { Increase of the employee pension contribution from } 9.5 \% \\
\text { to } 10 \%(2010)\end{array}$ \\
\hline & & Abolition of the $13^{\text {th }}$ pension \\
\hline & & $\begin{array}{l}\text { Freeze of nominal gross salaries and family allowances for } \\
\text { two years (2009-10) }\end{array}$ \\
\hline & & Abolition of the $13^{\text {th }}$ wage for public sector jobs \\
\hline & & Increase in the standard VAT rate from $20 \%$ to $25 \%$ (2009) \\
\hline \multirow[t]{2}{*}{ Poland } & \multirow{2}{*}{$\begin{array}{l}2.30 \% \text { (reduced from } \\
7.20 \% \text { as of } 1 \text { May } 2011 ; \\
\text { starting in 2013, } \\
\text { contributions will } \\
\text { gradually increase to } \\
\text { reach } 3.50 \% \text { in } 2017 \text { ) }\end{array}$} & $\begin{array}{l}\text { Freeze of public sector wages, reduction of public sector } \\
\text { jobs by } 10 \%(2011)\end{array}$ \\
\hline & & $\begin{array}{l}\text { Increase in the VAT rates: the standard rate rose from } 22 \% \\
\text { to } 23 \% \text {, the reduced rates rose from } 3 \% \text { and } 7 \% \text { to } 5 \% \text { and } \\
8 \% \text { respectively (2011) }\end{array}$ \\
\hline \multirow[t]{5}{*}{ Romania } & \multirow{5}{*}{$\begin{array}{l}\text { Minor - postponed a } \\
\text { planned increase in } 2^{\text {nd }} \\
\text { pillar contributions in } \\
\text { 2010, but has begun } \\
\text { raising the contribution } \\
\text { rate in } 2011\end{array}$} & $\begin{array}{l}\text { Reduction of pensions and unemployment benefits by } \\
15 \%(2010)\end{array}$ \\
\hline & & $\begin{array}{l}\text { Increase in the retirement age to } 65 \text { for men and } 63 \text { for } \\
\text { women (2010) }\end{array}$ \\
\hline & & $\begin{array}{l}\text { Overall increase in contribution rates from } 27.5 \% \text { to } 31.3 \% \\
(2008)\end{array}$ \\
\hline & & $\begin{array}{l}\text { Reduction of wages in the public sector by } 25 \% \text {, lay-offs of } \\
\text { public workers (2010) }\end{array}$ \\
\hline & & Increase in the VAT rate from $19 \%$ to $24 \%$ (2011) \\
\hline \multirow[t]{2}{*}{ Slovakia } & No change & $10 \%$ wage fund cut for some groups of public sector (2011) \\
\hline & & Increase in the VAT rate from $19 \%$ to $20 \%$ (2011) \\
\hline
\end{tabular}

* See "Pension System in Estonia", on the Estonia.eu website (http://estonia.eu/aboutestonia/society/pension-system-in-estonia.html).

** See the Investment in Pensions in Europe website (http://www.ipe.com/news/vast-majority-ofhungarys-second-pillar-members-return-to-state-system_39050.php); see also "Hungary: The second pillar of the pension system survives in a stripped down form", on the OSW (Centre for Eastern Studies) website (http://www.osw.waw.pl/en/publikacje/ceweekly/2011-02-02/hungary-second-pillarpension-system-survives-a-stripped-down-form).

Source: Author's compilation.

On the other hand, it should also be noted that these developments do not invalidate arguments about the path dependency as presented above:

- $\quad$ These steps were taken under extreme financial stress, when the governments had to undertake a whole set of radical measures that would also be unthinkable under normal circumstances. A list of such measures is shown in Table 2. The only country where there was no change whatsoever was Slovakia, the sole government in the sample not to undertake any fiscally restrictive measures during the crisis.

- Reversals tried to avoid formal abolition of the pillars and 'only' decreased their size, in most cases 'temporarily'. So far, the temporary reversals have been extended completely or to a large extent. 


\section{Flat income tax and its surprising survival}

Between 1994 and 2011, eight out of the ten post-communist EU member states introduced a flat income tax (see Table 3 for details). In the process, the flat income tax has become a powerful political symbol of liberal economic policies. In reality, the flat tax can take many different forms disguised under the same label. The tax rate can be the same or different for corporate and personal income taxes. The reform can consist of a fundamental tax reform or simply unify rates within the existing framework of the tax system. Very importantly, the rate itself can vary - in our sample of countries it has ranged from $10 \%$ to $33 \%$.

Table 3. Basic information on the introduction of the flat income tax

\begin{tabular}{lcrrrr}
\hline Country & Date of reform adoption & \multicolumn{2}{c}{ Tax rates before reform } & \multicolumn{2}{r}{ Tax rates after reform } \\
\cline { 3 - 6 } & & CIT (\%) & PIT (\%) & CIT (\%) & PIT (\%) \\
\hline Estonia & 1.1 .1994 & above 26 & $16-33$ & 26 & 26 \\
Lithuania & 1.1 .1995 & 29 & $18-33$ & 29 & 33 \\
Latvia & 1.1 .1997 & 25 & 10 and 25 & 25 & 25 \\
Slovakia & 1.1 .2004 & 25 & $10-38$ & 19 & 19 \\
Romania & 1.1 .2005 & 25 & $18-40$ & 16 & 16 \\
Bulgaria & CIT 1.1.2007, PIT 1.1.2008 & 15 & $10-24$ & 10 & 10 \\
Czech & 1.1 .2008 & 24 & $12-32$ & 22 & 15 \\
Republic & & & & & \\
Hungary & 1.1 .2011 & 10 and 19 & 17 and 32 & 16 (in 2013) & 16 \\
\hline
\end{tabular}

Note: The rates cited as 'after reform' are the rates immediately after the reform and many have changed since then.

Source: Author's compilation.

Similar to pension reforms, the flat tax was generally introduced by centre-right governments or governments that mixed parties from both sides of the political spectrum only in Lithuania was the flat tax introduced by a government dominated by the left. Unlike the pension reforms, the flat tax was generally controversial, and in many countries, even highly unpopular at the time of its introduction. Table 4 shows the detailed data. In five countries (namely Estonia, Slovakia, Romania, the Czech Republic and Hungary), the level of controversy was considered high, with significant social resistance and opposition statements about its abolition after election victory. In no case was it initially uncontested.

Therefore, one cannot look for the explanation of flat tax sustainability in a high level of public support or a low level of partisanship. On the contrary, based on these indicators, the sustainability of the flat tax seemed significantly lower than in the case of private pensions. Nonetheless, none of the new governments have abolished the flat tax. Indeed, subsequent changes in the flat tax until the crisis were generally in the direction of lowering the tax rate rather than making the system more progressive. Specifically, in the Baltic countries, there was a lowering of the tax rate. There were no substantial changes in Bulgaria, the Czech Republic, Hungary or Romania, except for those already enacted at the time of passage. In Slovakia, changes were undertaken to increase the progressivity of the income tax, but within the intellectual framework of the flat tax: in 2007, the government introduced a higher tax for high-income workers by abolishing the basic allowance for high earners, but preserving the $19 \%$ rate for PIT and CIT. 
Table 4. Political opposition towards the flat tax

\begin{tabular}{|c|c|c|c|c|c|}
\hline \multirow[t]{2}{*}{ Country } & \multirow{2}{*}{$\begin{array}{l}\text { Ideology of } \\
\text { government } \\
\text { implementing } \\
\text { the reform and } \\
\text { year of the } \\
\text { reform }\end{array}$} & \multirow{2}{*}{$\begin{array}{l}\text { Level of } \\
\text { controversy }\end{array}$} & \multirow{2}{*}{$\begin{array}{l}\text { View of the } \\
\text { main } \\
\text { opposition } \\
\text { party }\end{array}$} & \multicolumn{2}{|c|}{ Subsequent government } \\
\hline & & & & $\begin{array}{l}\text { Year of } \\
\text { appointment }\end{array}$ & Ideology \\
\hline Estonia & $\begin{array}{l}\text { Centre-right } \\
\text { (1994) }\end{array}$ & High & $\begin{array}{l}\text { Strongly } \\
\text { negative }\end{array}$ & 1995 & Centre-left \\
\hline Lithuania & $\begin{array}{l}\text { Centre-left } \\
\text { (1995) }\end{array}$ & Medium & Negative & 1998 & $\begin{array}{l}\text { Nationalist- } \\
\text { centre-right }\end{array}$ \\
\hline Latvia & $\begin{array}{l}\text { Broad coalition } \\
\text { (1997) }\end{array}$ & n.a. & n.a. & 1996 & $\begin{array}{l}\text { Conservative- } \\
\text { liberal }\end{array}$ \\
\hline Slovakia & $\begin{array}{l}\text { Centre-right } \\
(2004)\end{array}$ & High & $\begin{array}{l}\text { Strongly } \\
\text { negative }\end{array}$ & 2006 & $\begin{array}{l}\text { Nationalist- } \\
\text { centre-left }\end{array}$ \\
\hline Romania & $\begin{array}{l}\text { Centre-right } \\
\text { (2005) }\end{array}$ & High & Negative & 2008 & $\begin{array}{l}\text { Different } \\
\text { composition of } \\
\text { centre-right }\end{array}$ \\
\hline Bulgaria & $\begin{array}{l}\text { Mixed: left + } \\
\text { liberal (2007) }\end{array}$ & Medium & Negative & -2009 & Centre-right \\
\hline $\begin{array}{l}\text { Czech } \\
\text { Republic }\end{array}$ & $\begin{array}{l}\text { Centre-right } \\
(2008)\end{array}$ & High & $\begin{array}{l}\text { Strongly } \\
\text { negative }\end{array}$ & 2010 & Centre-right \\
\hline Hungary & Right (2011) & High & $\begin{array}{l}\text { Strongly } \\
\text { negative }\end{array}$ & n.a. & n.a. \\
\hline
\end{tabular}

Source: Author's compilation.

Looking at the costs and benefits of policy reversal (prior to the crisis), the political economy of the tax policy with regard to the median voter should work against a flat tax, as analysed in section 2. The explanation for its survival lies in a combination of the two remaining factors: strong signalling effects and low potential fiscal benefits of policy reversal.

Introduction of the flat tax served as a powerful symbol of the overall turn towards more market-oriented economic policies. To understand this, let us use an analogy with an older, more widespread and better-researched phenomenon - central bank independence. Maxfield (1997) finds that politicians use central bank independence to signal creditworthiness to foreign investors and counterparts. McNamara (2002) presents a sociological argument that delegation is based on the symbolic properties of central bank independence - "signalling agreement with a broader series of economic management principles and conveying credibility to external audiences about the economic and political character of a government" (p. 67). This view is shared by Cukierman et al. (2001) as a reason for the high level of central bank independence granted by transition countries to their monetary policy-makers. Hetzel (1990) argues that the degree of central bank independence depends on the country's commitment to a free market economy based on voluntary exchange coordinated by the price system, open competition for control over resources and a stable set of property rights. An independent central bank is, in this view, a bulwark of the market economy and limited government involvement.

A similar logic seems to operate for the flat tax, which "has commonly - almost universally been adopted by new governments anxious to signal a fundamental regime shift, towards 
more market-oriented policies. In several cases, the signal appears to have been wellreceived" (Keen et al., 2006, p. 37). This argument is stronger for the 'second generation' flattax reforms introduced in the 2000s in Central Europe and the south-east Balkans than the 'first generation' Baltic states in the 1990s, where flat taxes were introduced with relatively high rates.

A subsequent reversal of such a policy would send an explicit signal that the government is going to deviate from a pro-investment and pro-business economic policy. While such a signal might be mildly welcome by parts of the electorate, the political gain would probably be dwarfed by the political losses resulting from the worsening of the perceived business and investment climate. As Drahokoupil demonstrates in his 2009 book on Globalization and the State in Central and Eastern Europe, all new member states with the exception of Slovenia gradually converged on the model of a "competition state" with an extremely high share of foreign direct investment (FDI) in key sectors of the economy (Drahokoupil, 2009). In such an environment, the importance of external signalling cannot be overstated. For the organised interests opposing the flat tax (i.e. trade unions), abolition of the flat tax would be a welcome, but non-essential measure, relatively low on the priority list. Trade unions prefer to focus on measures strengthening their own position (labour market legislation) or 'positive' measures for their favoured social groups (higher benefits, public sector salaries), etc.

The flat tax also does not tie the hands of the government in the ways imagined by some of the public choice proponents of the system (Brennan \& Buchanan, 1977), since the system is flexible enough for governments to impose their policy preferences without losing the signal mentioned by Keen et al. (2006). We have already demonstrated that the flat tax as a policy idea is primarily a matter of political packaging rather than a distinct piece of economic policy. For example, a study on the impact of introducing the flat tax in the Czech Republic and Slovakia on labour taxation came to the conclusion that the flat tax meant a reduction in the labour income tax wedge for an overwhelming majority of workers. At the same time, the study showed that it increased rather than decreased the differences between the treatment of labour and capital income despite an identical tax rate (Beblavý \& Prousková, 2010). Similarly, the World Bank showed that an actual flat income tax can be even more progressive than the previously implemented "progressive" income tax, as in the case of Slovakia (World Bank, 2005).

From a fiscal point of view, a subsequent reversal of the flat tax would not have significant fiscal benefits. This is shown in Table 5. By the time the flat tax was introduced, the revenue from taxes on income and wealth ranged from 5 to $9 \%$ of GDP, compared with more than $13 \%$ for the old member states.

The fact that the introduction of the flat tax was not responsible for the lower revenue is also documented by a comparison of countries that later introduced a flat tax with postcommunist countries that did not. The future 'flat-taxers' had revenue from income and wealth taxes of $8.9 \%$ of GDP in 1995 and $7.9 \%$ of GDP in 2008, but the countries that never introduced the flat tax (Hungary, Poland and Slovenia) saw a nearly identical decline from $8.9 \%$ of GDP to $8.3 \%$ of GDP. In 2009, the revenues in flat tax countries declined more precipitously, but this was related to the greater effect of the global crisis on Baltic and Balkan countries than on Central Europe.

In other words, it was the transition and not the flat tax that was associated with a significant decline of revenue from income taxes over the medium term. A similar picture emerges from a comparison of the share of income in public revenues, which is not presented here in the interest of brevity. Therefore, transition led to an increasing gap between EU member states from Central and Eastern Europe and Western Europe in terms of revenue raised from income taxes, but this gap does not seem to be related to the policy decision to introduce a 
flat income tax. Rather, the explanation seems to lie either in the declining capacity of the state to extract revenue following the liberalisation of the economy or a conscious policy to stimulate growth and investment regardless of whether the policy took shape in a flat tax.

Table 5. Current revenues from taxes on income (\% of GDP)

\begin{tabular}{lccccccccccccccc}
\hline & $\mathbf{1 9 9 5}$ & $\mathbf{1 9 9 6}$ & $\mathbf{1 9 9 7}$ & $\mathbf{1 9 9 8}$ & $\mathbf{1 9 9 9}$ & $\mathbf{2 0 0 0}$ & $\mathbf{2 0 0 1}$ & $\mathbf{2 0 0 2}$ & $\mathbf{2 0 0 3}$ & $\mathbf{2 0 0 4}$ & $\mathbf{2 0 0 5}$ & $\mathbf{2 0 0 6}$ & $\mathbf{2 0 0 7}$ & $\mathbf{2 0 0 8}$ & $\mathbf{2 0 0 9}$ \\
\hline BG & 9.4 & 8.1 & 8.7 & 8.1 & 8.3 & 8.0 & 8.6 & 9.0 & 9.5 & 9.5 & 9.1 & 9.1 & 9.4 & 7.9 & 7.3 \\
CZ & 9.4 & 8.1 & 8.7 & 8.1 & 8.3 & 8.0 & 8.6 & 9.0 & 9.5 & 9.5 & 9.1 & 9.1 & 9.4 & 7.9 & 7.3 \\
EE & 10.9 & 9.2 & 9.2 & 10.3 & 9.7 & 7.7 & 7.2 & 7.5 & 8.0 & 7.9 & 7.0 & 7.1 & 7.6 & 7.9 & 7.5 \\
HU & 8.4 & 8.8 & 8.5 & 8.5 & 9.0 & 9.4 & 9.8 & 9.8 & 9.2 & 8.7 & 8.7 & 9.1 & 9.9 & 10.2 & 9.5 \\
LV & 7.1 & 7.0 & 7.5 & 8.0 & 7.7 & 7.1 & 7.4 & 7.6 & 7.3 & 7.7 & 7.7 & 8.3 & 8.8 & 9.5 & 7.0 \\
LT & 8.3 & 7.9 & 8.7 & 8.9 & 9.1 & 8.4 & 7.8 & 7.4 & 7.9 & 8.7 & 9.0 & 9.6 & 9.2 & 9.3 & 6.0 \\
RO & 10.6 & 9.8 & 9.5 & 8.3 & 7.3 & 6.4 & 5.8 & 5.4 & 5.7 & 6.1 & 5.1 & 5.7 & 6.4 & 6.4 & 6.3 \\
SK & 8.0 & 7.0 & 6.9 & 6.5 & 5.8 & 4.9 & 4.9 & 4.7 & 4.9 & 4.3 & 4.4 & 4.6 & 5.2 & 5.9 & 5.2 \\
Average & 8.9 & 8.4 & 8.5 & 8.4 & 8.1 & 7.3 & 7.4 & 7.2 & 7.3 & 7.3 & 7.0 & 7.3 & 8.0 & 7.9 & 6.8 \\
PL, SI & 8.9 & 8.9 & 8.8 & 8.7 & 7.2 & 6.9 & 6.8 & 6.9 & 6.9 & 6.9 & 7.4 & 7.9 & 8.4 & 8.3 & 7.4 \\
EU-15 & 13.1 & 13.6 & 13.9 & 14.1 & 14.1 & 14.5 & 14.2 & 13.7 & 13.4 & 13.3 & 13.6 & 13.9 & 14.0 & 13.8 & 13.2 \\
\hline
\end{tabular}

Note: The red shaded square indicates the year in which the flat tax was introduced. In Estonia, the flat tax was introduced in 1994, so it is outside the scope of the data. In Hungary, the flat tax was introduced in 2011, so it is also outside the scope of the data.

Source: Eurostat.

We can also examine the immediate impact of the introduction of the flat tax by comparing revenue from income taxes in the year before the change with the two years following the change. The results - presented in Table 6 - are that the introduction of the flat tax is, on average, associated with no measurable drop in revenue as a \% of GDP in the following two years. Instead, we can see that for some countries, the introduction of a flat tax was associated with significant revenue increases (Bulgaria and Latvia), while for others it involved revenue losses (the Czech Republic, Romania and Slovakia).

Table 6. Revenue from current taxes on income and from social security contributions as a of GDP before and after the introduction of a flat tax

\begin{tabular}{lcccrrr}
\hline & \multicolumn{3}{c}{ Income tax revenue } & \multicolumn{3}{c}{ Social security contributions } \\
\cline { 2 - 7 } & Year n-1 & Year $\mathbf{n}$ & Year $\mathbf{n + 1}$ & Year n-1 & Year n & Year $\mathbf{n + 1}$ \\
\hline Bulgaria & 4.7 & 7.6 & 6.1 & 8.3 & 8.1 & 7.8 \\
Czech Republic & 9.4 & 7.9 & 7.3 & 16.3 & 16.2 & 15.4 \\
Latvia & 7.0 & 7.5 & 8.0 & 10.8 & 10.6 & 10.8 \\
Romania & 6.1 & 5.1 & 5.7 & 9.7 & 9.8 & 9.8 \\
Slovakia & 4.9 & 4.3 & 4.4 & 10.0 & 9.9 & 9.9 \\
Average & 6.4 & 6.5 & 6.3 & 11.0 & 10.9 & 10.7 \\
\hline
\end{tabular}

Note: The data exclude Estonia, Hungary and Lithuania due to data unavailability; however, given the very high revenues in Estonia and Lithuania after the introduction of a flat tax, it is unlikely their inclusion would decrease the post-introduction revenue.

Source: Author's compilation based on Eurostat. 
The ability of new member state governments to use income tax as a cheap signalling device is reinforced by the imbalance between income tax revenue and social security contributions. While on average these are roughly equal in Western Europe, oscillating at around $13 \%$ of GDP, Table 6 shows that they play a much more important role in the new member states introducing the flat tax, with nearly double the income coming from social security contributions.

As we saw in the section on pensions, the crisis brought radically increased fiscal pressures. Yet this did not lead to an abolition of the flat income tax; on the contrary, Hungary introduced it in 2011 as a part of its recovery package. A shift to a progressive income tax was discussed in Baltic countries, but in the end they opted either for a further decrease in the tax rate (Lithuania) or a partial reversal of previous cuts in the tax rate (Estonia and Latvia). In other countries, no significant change occurred. One could argue that, with the exception of Slovakia, flat tax countries were generally governed by centre-right parties during the crisis and that the ideological argument could explain why the flat tax survived. The same fact did not prevent reversals in the second pillar, however. The difference appears to be the continuing combination of a potent signalling of a 'competition state' and the low potential fiscal benefits of policy reversal.

\section{Synthesis and conclusion}

In this paper, we have examined two questions related to the sustainability of major, neoliberal, economic and social reforms in the new EU member states, namely the flat income tax and private pension pillars. First, we have looked at the relationship between the political consensus/controversy at the time major policy reforms were passed and the future sustainability of these reforms after a change of government. Second, we have explored the paradox of reverse sustainability, whereby the flat income tax has been more politically resilient during the global financial and economic crisis than private pensions, even though ex ante expectations and the literature would lead us to expect the opposite.

Table 7 shows a stylised summary of the effect of various explanatory factors on the introduction/sustainability of private pensions and a flat income tax based on findings from the previous two sections. We have assessed the effect for three periods - introduction, a change of government and the crisis. The picture is stylised in the sense that we are synthesising the experience of nine countries over different periods of time, so we are drawing out the common themes and findings rather than taking full account of each individual story.

The table shows that controversy at the time the reforms were passed had no effect on the subsequent sustainability, and that the level of partisanship and public support with regard to a specific reform seem less important than the political costs and benefits.

Both reforms had strong constituencies in their favour. For private pensions, it was the millions of individuals who voluntarily entered the savings system. For the flat income tax, the constituency was the domestic and particularly the foreign business and investment community, to which the new system sent a strong signal about the overall government's economic and social policy mix. The position occupied by this constituency should be evaluated in the light of the extremely important role played by FDI in the developmental strategy of the Central and Eastern European 'competition state'. On the other hand, trade unions as the major opponents of both changes in several countries have been weak and haemorrhaging support during the 1990s and 2000s. 
Table 7. Influence of various factors on the introduction and sustainability of private pension and flat tax reforms

\begin{tabular}{|c|c|c|c|c|c|c|c|}
\hline & \multicolumn{3}{|c|}{ Pensions } & \multicolumn{3}{|c|}{ Income tax } \\
\hline & & Introduction & $\begin{array}{l}\text { Change } \\
\text { of govt }\end{array}$ & Crisis & Introduction & $\begin{array}{l}\text { Change } \\
\text { of govt }\end{array}$ & Crisis \\
\hline \multirow{2}{*}{$\begin{array}{l}\text { Partisanship/ } \\
\text { public } \\
\text { support }\end{array}$} & $\begin{array}{l}\text { Ideology of } \\
\text { government }\end{array}$ & + & - & + & + & - & + \\
\hline & $\begin{array}{l}\text { Level of } \\
\text { controversy }\end{array}$ & $0 /-$ & $0 /$ & $0 /-$ & - & - & - \\
\hline \multirow[t]{3}{*}{$\begin{array}{l}\text { Political costs } \\
\text { and benefits }\end{array}$} & $\begin{array}{l}\text { Interests/ } \\
\text { path } \\
\text { dependency }\end{array}$ & 0 & + & + & + & + & + \\
\hline & $\begin{array}{l}\text { Fiscal } \\
\text { benefit/cost }\end{array}$ & - & - & - & 0 & 0 & 0 \\
\hline & $\begin{array}{l}\text { Fiscal } \\
\text { pressure }\end{array}$ & 0 & 0 & + & 0 & 0 & + \\
\hline Sustainability & & n.a. & High & $\begin{array}{l}\text { Low- } \\
\text { medium }\end{array}$ & n.a. & High & High \\
\hline
\end{tabular}

Note: + means a positive influence on introduction/sustainability, - means a negative influence, 0 means no or an insignificant influence

Source: Author's compilation.

We have also found that despite their apparent neoliberal bent, the two policies are versatile enough to be shaped towards a variety of policy goals, allowing their introduction and retention in a variety of economic and social circumstances. In other words, even though private pensions and particularly the flat tax have powerful political connotations, they are by no means policy straitjackets.

While both reforms could sustain themselves throughout the 'good' times before the global crisis, their fates diverged during the crisis. Neither public support nor the large constituency of savers could fully protect private pensions from a policy reversal during a period of exceptional fiscal pressure. That is because the reversal was associated with significant, short-term fiscal gains and the states where these reversals took place also took a range of other decisions that were politically extraordinarily difficult. At the same time, we have demonstrated that the introduction or potential reversal of the flat tax was not associated with significant, short-term revenue gains. It is the relatively 'cheap' nature of the flat tax that distinguishes it from private pensions, because it sends a highly cost-effective signal in terms of revenue lost owing to the existence of the reform.

Overall, we can see that these reforms have been politically sustained by factors that made them politically attractive in the first place. With the exception of the lock-in effect created by ownership of their private savings in the pensions, other factors contributing to the sustainability of the liberal economic policies in the new EU member states were also present at their introduction. 


\section{References}

Ashworth, J. and B. Heyndels (2001), "Political Fragmentation and the Evolution of National Tax Structures in the OECD", International Tax and Public Finance, Vol. 8, pp. 377-393.

Beblavý, M. (2009), "Comparative analysis of determinants and effects of social protection spending in the new EU member states", in P. Saunders and R. Sainsbury (eds), Social security, poverty and social exclusion in rich and poorer countries, Antwerp: Intersentia, pp. 113-132.

Beblavý, M. and E. Prousková (2010), “Flat Tax and Labour Taxation - The Czech and Slovak Experience", Journal of Economics, No. 8/2010.

Barr, N. (2006), "Pensions: Overview of the issues", Oxford Review of Economic Policy, Vol. 22, No. 1, pp.1-14.

Bird, R.M. (2004), "Managing Tax Reform", International Bureau of Fiscal Documentation, Bulletin, February.

Bohn, H. and C. Stuart (2003), Voting and Nonlinear Taxes in a Stylized Representative Democracy, CESifo Working Paper No. 1058, CESifo, Munich.

Bonoli, G. (2003), “Two Worlds of Pension Reform in Western Europe”, Comparative Politics, Vol. 35, No. 4, published by the PhD Program in Political Science of the City University of New York, July, pp. 399-416.

Brennan, G. and J. Buchanan (1977), “Towards a Tax Constitution for Leviathan”, Journal of Public Economics, Vol. 8, pp. 3255-73.

Castles, F., S. Leibfried, J. Lewis, H. Obinger and C. Pierson (2010), The Oxford Handbook of the Welfare State, Oxford: Oxford University Press.

Clark, G.L. (2006), "The UK occupational pension system in crisis", in H. Pemberton, P. Thane and N. Whiteside (eds), Britain's Pensions Crisis: History and Policy, London: Oxford University Press for the British Academy, pp. 145-168.

Cukierman, A., G. Miller and B. Neyapti (2001), Central Bank Reform, Liberalization and Inflation in Transition Economies - An International Perspective, CEPR Discussion Paper No. 2808, CEPR, London.

Cukierman, A. and M. Tommasi (1998), "Credibility of Policymakers and of Economic Reforms", in F. Sturzenegger and M. Tommasi (eds), The Political Economy of Economic Reforms, Cambridge: MIT Press.

Dewatripont, M. and G. Roland (1992), “Economic Reform and Dynamic Political Constraints", Review of Economic Studies, Vol. 59, No. 4, October, pp. 703-730.

(1995), "The Design of Reform Packages under Uncertainty", American Economic Review, Vol. 85, No. 5, December, pp. 1207-1223.

Drahokoupil, J. (2009), “Globalization and the State in Central and Eastern Europe: The Politics of Foreign Direct Investment", Journal of Contemporary Central and Eastern Europe, Vol. 17, No. 2.

Draxler, J. and O. van Vliet (2010), "European Social Model: No Convergence from the East", Journal of European Integration, Vol. 32, No. 1, pp. 115-135.

Esping-Andersen, G. (1990), The three worlds of welfare capitalism, Princeton: Princeton University Press. 
Ferrera, M. and M. Rhodes (2000), Recasting European welfare states, Chippenham, Wiltshire: Antony Rowe Ltd.

Fernandez, R. and D. Rodrik (1991), "Resistance to Reform: Status Quo Bias in the Presence of Individual-Specific Uncertainty", American Economic Review, Vol. 35, No. 5, pp. 114655.

Hall, P.A. (1990), "Policy paradigms, experts and the state: The case of macroeconomic policymaking in Britain", in S. Brooks and A.-G. Gagnon (eds), Social scientists, policy, and the state, New York, NY: Praeger.

Hering, M. (2006), “The Politics of Structural Pension Reform in Western Europe: Does the EU Matter?", paper presented at the Fifteenth International Conference of the Council for European Studies, 29 March-2 April, Chicago, IL.

Hetzel, R. (1990), “Central Banks' Independence in Historical Perspective: A Review Essay”, Journal of Monetary Economics, Vol. 25, No. 1, pp. 165-176.

Holzmann, R. (1999), A World Bank Perspective on Pension Reform, Social Protection Discussion Papers 20050, World Bank, Washington, D.C.

Inotai, A. (2000), "The Czech Republic, Hungary, Poland, the Slovak Republic, and Slovenia", in H. Tang (ed.), Winners and Losers of EU Integration: Policy Issues for Central and Eastern Europe, World Bank, Washington, D.C.

Keen, M., Y. Kim and R. Varsano (2006), The "Flat Tax(es)": Principles and Evidence, IMF Working Paper WP/06/218, International Monetary Fund, Washington, D.C.

Kim, B.-Y., and J. Pirtilla (2006), "Political Constraints and Economic Reform: Empirical Evidence from Post-Communist Transition in the 1990s", Journal of Comparative Economics, Vol. 34, No. 3, pp. 446-466.

Kohl, H. (2008), Where Do Trade Unions Stand Today in Eastern Europe? Stocktaking after EU Enlargement, International Trade Union Cooperation Briefing Paper No. 5, Friedrich Ebert Stiftung, Bonn.

Kuhn, T.S. (1962), The structure of scientific revolutions, Chicago, IL: University of Chicago Press.

Marier, P. (2008), Pension Politics: Consensus and Social Conflict in Ageing Societies, Abingdon: Routledge.

Masterman, M. (1970), “The nature of a paradigm", in I. Lakatos and A. Musgrave (eds), Criticism and the growth of knowledge, London: Cambridge University Press.

Maxfield, S. (1997), Gatekeepers of Growth, the International Political Economy of Central Banking in Developing Countries, Princeton: Princeton University Press.

McNamara, K. (2002), "Rational Fictions: Central Bank Independence and the Social Logic of Delegation", West European Politics, Vol. 25, No. 1, pp. 47-76.

Myles, J. (1988), "Decline of Impasse? The Current State of the Welfare State", Studies in Political Economy, Vol. 26, summer.

Natali, D. (2004), "The hybridation of pension systems within the EU enlarged: Recent reforms in old and new members", Belgian Review of Social Security, No. 2/04.

OECD (2009), How to implement pro-growth tax reforms, OECD, Paris.

(2010), Making Reform Happen: Lessons from OECD Countries, OECD, Paris. 
(2011), Pensions at a Glance 2011: Retirement-Income Systems in OECD and G20 Countries, OECD, Paris.

Olofsgard, A. (2003), The Political Economy of Reform: Institutional Change as a Tool for Political Credibility, background paper to the World Bank's 2005 World Development Report.

Pierson, P. (1994), Dismantling the Welfare State? Reagan, Thatcher, and the Politics of Retrenchment, Cambridge: Cambridge University Press.

Pierson, C. (1995), Beyond the Welfare State, Cambridge: Polity Press.

Profeta, P. (2003), "Political Support and Tax Reforms with an Application to Italy", Public Choice, Vol. 131, No. 1, pp. 141-155.

Rhodes, M. and D. Natali (2003), "Welfare Regimes and Pension Reform Agendas", contribution to the Conference on "Pension Reform in Europe: Shared Problems, Sharing Solutions", London School of Economics and Political Science, London, 5 December.

Sapir, A. (2006), "Globalization and the Reform of European Social Models", Journal of Common Market Studies, Vol. 44, No. 2, p. 369.

Simonovits, A. (2009), Hungarian Pension System and its Reform, Discussion Paper MT-DP 2009/8, Institute of Economics, Hungarian Academy of Sciences, Budapest.

Vaughan-Whitehead, D.C. (2003), EU enlargement versus social Europe? The uncertain future of the European Social Model, Cheltenham: Edward Elgar Publishing Ltd.

World Bank (2005), Living Standards Assessment: Slovakia, World Bank, Washington, D.C.

Wyplosz, C. (1993), "After the Honeymoon: On the Economics and the Politics of Economic Transformation", European Economic Review, Vol. 37, Nos 2-3, pp. 379-386.

Žitňanský, R. (2009), The influence of political consensus on sustainability of the $2^{\text {nd }}$ pension pillar, M.A. thesis, Institute of Public Policy of the Comenius University, Bratislava. 


\section{ABOUT CEPS}

Founded in Brussels in 1983, the Centre for European Policy Studies (CEPS) is widely recognised as the most experienced and authoritative think tank operating in the European Union today. CEPS acts as a leading forum for debate on EU affairs, distinguished by its strong in-house research capacity, complemented by an extensive network of partner institutes throughout the world.

\section{Goals}

- Carry out state-of-the-art policy research leading to innovative solutions to the challenges facing Europe today,

- Maintain the highest standards of academic excellence and unqualified independence

- Act as a forum for discussion among all stakeholders in the European policy process, and

- Providea regular flow of authoritative publications offering policy analysis and recommendations,

\section{Assets}

- Multidisciplinary, multinational \& multicultural research team of knowledgeable analysts,

- Participation in several research networks, comprising other highly reputable research institutes from throughout Europe, to complement and consolidate CEPS' research expertise and to extend its outreach,

- An extensive membership base of some 132 Corporate M embers and 118 Institutional Members, which provide expertise and practical experience and act as a sounding board for the feasi bility of CEPS policy proposals.

\section{Programme Structure}

\section{In-house Research Programmes}

\section{Economic and Social Welfare Policies}

Financial Institutions and Markets

Energy and Climate Change

EU Foreign, Security and Neighbourhood Policy

Justice and Home Affairs

Politics and Institutions

Regulatory Affairs

Agricultural and Rural Policy

\section{Independent Research Institutes managed by CEPS}

European Capital Markets Institute (ECMI)

European Credit Research Institute (ECRI)

\section{Research N etworks organised by CEPS}

European Climate Platform (ECP)

European N etwork for Better Regulation (ENBR)

European N etwork of Economic Policy

Research Institutes (ENEPRI)

European Policy Institutes N etwork (EPIN) 